\title{
Corticotropin-releasing hormone receptor-1 in human endometrial cancer
}

\author{
GRAZIA GRAZIANI ${ }^{1}$, GABRIELLA FERRANDINA $^{2}$, GIACOMO POZZOLI $^{3}$, MATTEO VERGATI $^{1}$, \\ ALESSIA MUZI $^{1}$, FRANCESCO LEGGE ${ }^{2}$, LUCIO TENTORI ${ }^{1}$, GIOVANNI SCAMBIA ${ }^{2}$ and PIERLUIGI NAVARRA ${ }^{3}$ \\ ${ }^{1}$ Department of Neuroscience, University of Rome 'Tor Vergata'; Departments of ${ }^{2}$ Gynecology/Obstetrics and \\ ${ }^{3}$ Pharmacology, Catholic University Medical School, Rome, Italy
}

Received July 13, 2005; Accepted August 23, 2005

\begin{abstract}
We have previously shown that corticotrophinreleasing hormone $(\mathrm{CRH})$ inhibits the proliferation of Ishikawa (IK) human endometrial carcinoma cell line through the activation of CRH-R1 receptors. Here, we have further investigated the role of $\mathrm{CRH}$ and its type-1 receptor in the control of IK cell function, and we carried out a pilot study in tumor tissues obtained from 19 patients with endometrial cancer, looking at CRH-R1 gene expression. In the IK study, $\mathrm{CRH}$ counteracted the increase in cell proliferation caused by estradiol; type-1 receptors mediating this effect belong to the a subtype. In the study on human tumors, CRH-R1 was expressed in 4 out of 19 (21\%) surgical specimens obtained from untreated patients with a diagnosis of primary endometrial cancer. Two out of 4 cases (50\%) expressing CRH-R1 mRNA had extrauterine spreading of the disease, whereas cases not expressing CRH-R1 mRNA were all FIGO stage I, $2(\mathrm{p}=0.015)$.
\end{abstract}

\section{Introduction}

Corticotropin-releasing hormone $(\mathrm{CRH})$ was initially characterized as a mediator of behavioral, autonomic and neuroendocrine responses to stress; some evidence, mostly from in vitro studies, suggests that CRH may also play a role in the control of neoplastic cell growth $(1,2)$. In the majority of cases, CRH appears to inhibit tumor cell proliferation, although a positive correlation between $\mathrm{CRH} / \mathrm{CRH}$ receptor expression and tumor progression has also been reported (3). In any case, the effect of $\mathrm{CRH}$ on the regulation of tumor cell growth depends on the presence of CRH receptors in these cells.

Reubi and colleagues (4) investigated the expression of $\mathrm{CRH}$ receptors, both CRH-R1 and -R2 subtypes, in >200 human cancers originating from tissues which may or may

Correspondence to: Professor Grazia Graziani, Department of Neuroscience, University of Rome 'Tor Vergata', Via Montpellier 1, 00133 Rome, Italy

E-mail: graziani@uniroma2.it

Key words: corticotropin-releasing hormone, CRH-R1 $\alpha$, receptor, Ishikawa cell line, estradiol, endometrial adenocarcinoma, human not express $\mathrm{CRH}$ receptors; the latter were found in pituitary adenomas, in pancreatic tumors and in tumors originating from the central and peripheral nervous system, but not in other tumors such as prostate, lung or colon carcinomas. The expression of $\mathrm{CRH}$ receptors in tumors originating from the female reproductive apparatus, where $\mathrm{CRH}$ exerts a variety of biological activities either under pregnant or non-pregnant conditions $(5,6)$, has never been investigated.

In a series of in vitro experiments, we have previously shown that $\mathrm{CRH}$ is able to inhibit the proliferation of a human endometrial adenocarcinoma cell line, Ishikawa (IK) cells; this effect was mediated through the stimulation of CRH-R1 receptors and the subsequent activation of the cAMP-PKA pathway (2). In the present study, we have further investigated the role of CRH and its type-1 receptor in IK cells, looking at receptor regulation and isoform expression, as well as at the functional interactions between CRH and estradiol (E2) in regulating IK cell proliferation. Evidence from IK cell line raised the question as to whether CRH-R1 is expressed in human endometrial cancers; for this purpose, we investigated CRH-R1 gene expression in tumor tissues obtained from patients with this type of malignancy.

\section{Materials and methods}

Cell line and experimental conditions. The human endometrial adenocarcinoma Ishikawa cell line was kindly provided by Professor Gigliola Sica (Institute of Histology, Catholic University Medical School, Rome). Cells were cultured in DMEM (Gibco, Paisley, Scotland, UK) supplemented with $10 \%$ fetal calf serum (Gibco), 2 mM L-glutamine, 100 units/ $\mathrm{ml}$ penicillin and $100 \mu \mathrm{g} / \mathrm{ml}$ streptomycin (Flow Laboratories, McLean, VA), at $37^{\circ} \mathrm{C}$ in a $5 \% \mathrm{CO}_{2}$ humidified atmosphere. In order to remove estrogenic components present in the serum and estrogenic contaminants in phenol red indicator, experiments were performed in phenol red-free DMEM (Gibco) containing 1 or $10 \%$ charcoal/dextran-stripped FBS (Hyclone, Logan, UT, USA), as specified, $1 \mathrm{mM}$ sodium pyruvate, $100 \mathrm{units} / \mathrm{ml}$ penicillin and $100 \mu \mathrm{g} / \mathrm{ml}$ streptomycin.

Cells were cultured in flasks (Falcon, Becton \& Dickinson Labware, Oxnard, CA, USA) ( $8 \times 10^{5}$ cells/flask). In experiments looking at interaction with estrogens, cells were treated with vehicle or with E2 (Sigma Biochemicals 
Table I. CHR-R1 mRNA expression and clinico-pathological parameters in endometrial cancer.

\begin{tabular}{cccccccc}
\hline Patient & $\begin{array}{c}\text { Age } \\
\text { (yrs. }\end{array}$ & Menopause & Istotype & Grading & $\begin{array}{c}\text { Myometrial } \\
\text { invasion }\end{array}$ & $\begin{array}{c}\text { FIGO } \\
\text { stage }\end{array}$ & CRH-R1 \\
\hline 1 & 37 & No & Endometrioid & 1 & M1 & IIB & + \\
2 & 54 & Yes & Endometrioid & 3 & M2 & IIIC & + \\
3 & 63 & Yes & Endometrioid & 2 & M1 & IB & + \\
4 & 65 & Yes & Endometrioid & 2 & M2 & IC & + \\
5 & 75 & Yes & Endometrioid & 3 & M1 & IB & - \\
6 & 69 & Yes & Endometrioid & 3 & M1 & IB & - \\
7 & 60 & Yes & Endometrioid & 3 & M1 & IB & - \\
8 & 43 & No & Endometrioid & 1 & M0 & IA & - \\
9 & 59 & Yes & Endometrioid & 2 & M1 & IB & - \\
10 & 61 & Yes & Endometrioid & 3 & M2 & IC & - \\
11 & 71 & Yes & Endometrioid & 2 & M1 & IB & - \\
12 & 66 & Yes & Endometrioid & 2 & M1 & IB & - \\
13 & 61 & Yes & Endometrioid & 2 & M1 & IB & - \\
14 & 76 & Yes & Endometrioid & 1 & M1 & IB & - \\
15 & 73 & Yes & Endometrioid & 1 & M1 & IB & - \\
16 & 54 & Yes & Mucinous & 1 & M0 & IA & - \\
17 & 71 & Yes & Endometrioid & 2 & M1 & IB & - \\
18 & 61 & Yes & Endometrioid & 1 & M1 & IB & - \\
19 & 69 & Yes & Endometrioid & 2 & M1 & IB & - \\
\hline
\end{tabular}

${ }^{\mathrm{a}}$ Myometrial invasion: $\mathrm{M} 0=$ absent, $\mathrm{M} 1 \leq 50 \%, \mathrm{M} 2 \geq 50 \%$.

Co., St. Louis, MO), given at concentrations ranging from 1 to $100 \mathrm{nM}$ either in the absence or in the presence of $100 \mathrm{nM}$ CRH. Cell counts were carried out as previously described (2) after 48 and $72 \mathrm{~h}$ of incubation. In experiments looking at receptor regulation, adherent cells were treated with $10^{-7} \mathrm{M}$ CRH (Sigma Biochemicals Co.), or with drug solvent only for 1, 3, 6 and $24 \mathrm{~h}$ of incubation. At the end of experiment, total RNA was extracted and analyzed for CRH-R1 gene expression as described below.

Patients. This study was conducted on 19 primary untreated endometrial cancer patients that were admitted, treated and followed-up at the Department of Obstetrics and Gynecology, Division of Gynecologic Oncology, Catholic University of Rome. The clinico-pathological characteristics of each case are listed in Table I. Staging was performed according to FIGO classification (7).

Median age was 63 years (range 37-76). Seventeen patients (89.4\%) were postmenopausal. Most patients (15/19, 78.9\%) were stage I, and only $4(27.1 \%)$ patients had extrauterine disease. Most of the tumors $(94.7 \%)$ were endometrioid adenocarcinomas and showed well (31.6\%), moderate (42.1\%), and poorly $(26.3 \%)$ differentiated grade. Two $(10.5 \%)$ cases had no myometrial invasion (M0) while $14(73.7 \%)$ and 3 $(15.8 \%$ ) cases showed $\leq 50 \%$ (M1) and $>50 \%$ invasion (M2) of myometrium thickness.

All patients were submitted to total abdominal or modified radical hysterectomy plus bilateral salpingo-oophorectomy. At time of laparotomy, fluid samples were obtained for cytologic examination and thorough intra-abdominal and pelvic exploration with biopsy or removal of any suspicious lesion was performed. Systematic pelvic and para-aortic lymphadenectomy was performed in 7 (36.8\%) high risk patients (poor grade of differentiation, deep myometrial invasion, cervical involvement, special histotypes). Only one case (pt. 2 in Table I) showed metastatic lymph node involvement.

RNase protection analysis. Total RNA was extracted by the guanidine thiocyanate lysis method of Chomczynski and Sacchi (8). To measure CRH-R1 mRNA expression, a plasmid (pGP-1) containing a 522-bp fragment of the human CRHR1 cDNA encoding the N-terminal 174 amino acids (2) was linearized with BamHI, and a 605-nucleotide antisense, of which 522 nucleotides would be protected by hybridization to the CRH-R1 transcript, was synthesized using T7 RNA polymerase in the presence of $\left[\alpha^{-32} \mathrm{P}\right] \mathrm{UTP}(800 \mathrm{Ci} / \mathrm{mmol})$.

Human glyceraldeide-3-phosphate dehydrogenase (hGAPDH) was used as an internal loading control (2). The hGAPDH plasmid (pTRI, Ambion, Austin, TX) was linearized with Sty1, and an antisense riboprobe of 244 nucleotides, resulting in a protected fragment of 134 nucleotides, was synthesized with SP6 RNA polymerase and $\left[\alpha^{-32} \mathrm{P}\right]$ UTP (400 Ci/mmol).

RNase protection analyses were performed (9) by hybridizing $25 \mu \mathrm{g}$ total RNA in $24 \mu \mathrm{l}$ deionized formamide plus $6 \mu 1$ hybridization buffer containing $5 \times 10^{5} \mathrm{cpm}$ CRH-R1 and $8000 \mathrm{cpm}$ hGAPDH riboprobes. After heating at $80^{\circ} \mathrm{C}$, the samples were hybridized at $45^{\circ} \mathrm{C}$ for $15 \mathrm{~h}$ and subsequently 


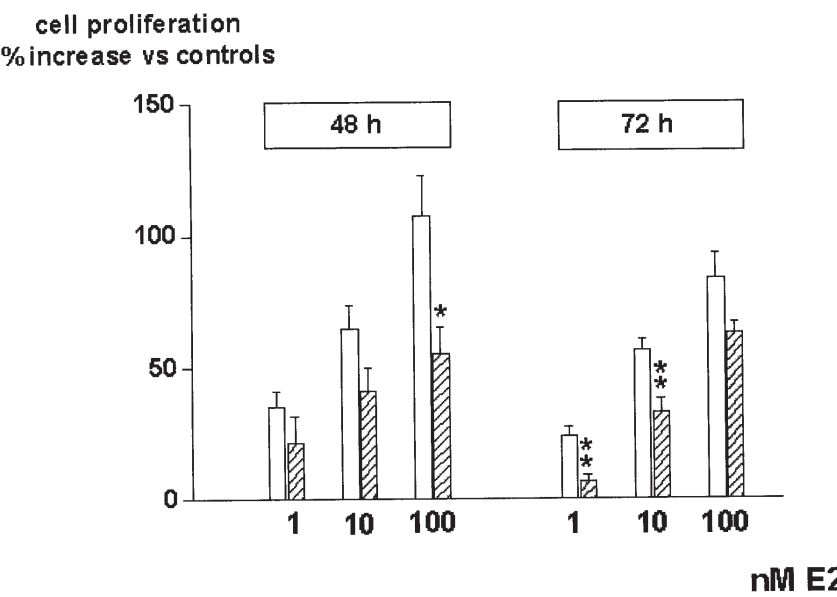

Figure 1. CRH $10^{-7} \mathrm{M}$ significantly counteracts the increase in IK cell proliferation induced by E2 in the range of $10^{-7}-10^{-9} \mathrm{M}$. Experiments carried out in the absence (empty bars) or in the presence (hatched bars) of $10^{-7} \mathrm{M}$ $\mathrm{CRH}$. Results from two different experiments carried out in triplicate are expressed as percent increases in cell proliferation calculated against the respective controls (vehicle for empty bars, or $\mathrm{CRH}$ alone for hatched bars). Data are the means \pm SEM of 6 replicates per group. ${ }^{*} \mathrm{p}<0.05$ and ${ }^{* *} \mathrm{p}<0.01$ vs. E2 alone.

digested by RNase $(200 \mu \mathrm{g} / \mathrm{ml}$ RNase A and $350 \mathrm{U} / \mathrm{ml}$ RNase $\mathrm{T} 1)$ at room temperature for $60 \mathrm{~min}$. The samples were resolved on 5\% polyacrylamide-8 $\mathrm{M}$ urea gels. Quantitative analysis was performed using the ImageMaster ${ }^{\circledR}$ VDS and the Imagesystem software package (Amersham-Pharmacia Biotech, San Francisco, CA).

$R T-P C R$. Total RNA was treated with RNAse-free DNAse and cDNA was synthesized by incubating $1.5 \mu \mathrm{g}$ RNA with $0.5 \mathrm{U}$ of AMV RT and $0.2 \mu \mathrm{g}$ oligo(dT) primer at $42^{\circ} \mathrm{C}$ for $1 \mathrm{~h}$, using the cDNA Cycle ${ }^{\circledR}$ kit from Invitrogen. Aliquots of the reversetranscribed cDNA $(5 \mu \mathrm{l})$ were subjected to 30 cycles of PCR in $50 \mu \mathrm{l}$ of $1 \mathrm{X}$ buffer (10 mM Tris- $\mathrm{HCl}, \mathrm{pH} 8.3,1.5 \mathrm{mM} \mathrm{MgCl}_{2}$, $50 \mathrm{mM} \mathrm{KCl}$ ) containing $1 \mathrm{mM}$ each of dATP, dCTP, dGTP and dTTP, $2.5 \mu \mathrm{Ci}$ of $\alpha\left[{ }^{32} \mathrm{P}\right] \mathrm{dCTP}, 2.5 \mathrm{U}$ of Taq DNA polymerase (Roche, Milan, Italy) and $0.2 \mathrm{mM}$ of specific primers. Each cycle consisted of denaturation at $94^{\circ} \mathrm{C}$ for $45 \mathrm{sec}$, annealing for $45 \mathrm{sec}$ and extension at $72^{\circ} \mathrm{C}$ for $90 \mathrm{sec}$. The primer pairs used for CRH-R1 were: 5'-GGCAGCTAGTGG TTCGGCC-3' and 5'-TCGCAGGCACCGGATGCTC-3' for type $\alpha$ (accession number: L23332) and 5'-GGCCAGGCTG CACCCATTG-3' and 5'-TCGCAGGCACCGGATGCTC-3' for type $\beta$ (accession number: L23333), which amplified a 272- and 107-bp fragment, respectively. The primers used for GAPDH analysis (5'-TGGTATCGTGGAAGGACTCA TGAC-3' and 5'-ATGCCAGTGAGCTTCCCGTTCAGC-3') amplified a 190-bp product.

PCR reaction $(20 \mu \mathrm{l})$ were electrophoresed through a $2 \%$ agarose gel containing ethidium bromide.

Statistical analysis. Data of proliferation experiments were expressed as percent increases versus control, the means \pm standard error of the mean (SEM) of 6 replicates per group. Data were analyzed by ANOVA and the post-hoc NewmanKeul test for multiple comparisons among group means. Differences were considered significant at $\mathrm{p}<0.05$.

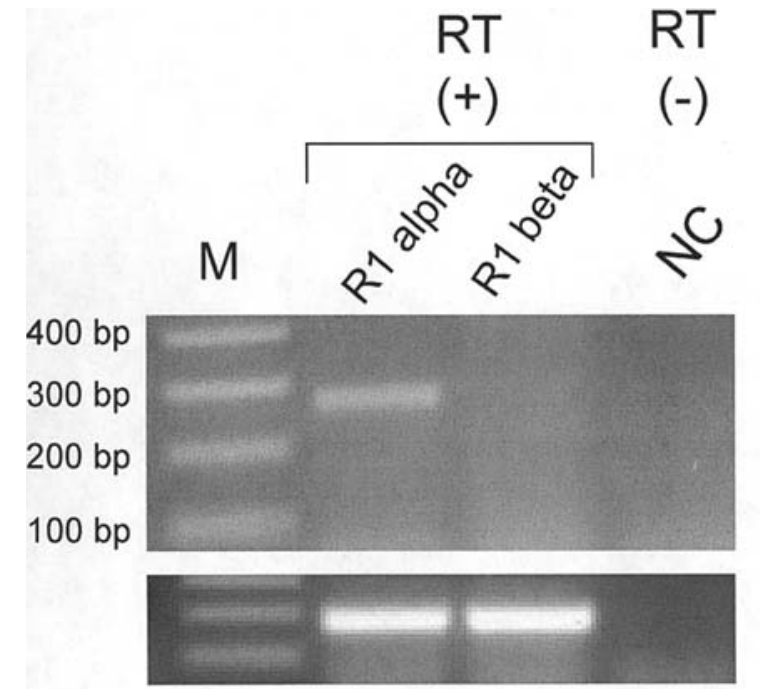

GAPDH

Figure 2. Analysis of CRH-R1 transcript. The expression of CRH-R1 alpha or beta and of GAPDH mRNA was assessed by RT-PCR, as described in Materials and methods. M: $1 \mathrm{~kb}$ plus ladder (Gibco). NC, negative control. Representative of three different experiments with similar results.

In the human study, the distribution of CRH-R1 mRNA expression values according to clinico-pathological characteristics was performed by Fisher's exact test for proportion.

\section{Results}

The addition of $\mathrm{CRH} 10^{-7} \mathrm{M}$ to IK cells was previously found to cause a concentration- and time-dependent decrease in cell proliferation under basal conditions (2). $\mathrm{CRH} 10^{-7} \mathrm{M}$ was also able to significantly counteract the increase in cell proliferation induced by estradiol (E2) in the range $10^{-9}-10^{-7} \mathrm{M}$ (Fig. 1). Such inhibitory effect might possibly be explained by downregulation of estrogen receptor- $\alpha$ (ER- $\alpha$ ) induced by $\mathrm{CRH}$. However, $10^{-7} \mathrm{M} \mathrm{CRH}$ had no effect on ER- $\alpha$ gene expression in 24- and 48-h incubation experiments (not shown).

In this study, we used the RT-PCR approach to confirm our previous finding of CRH-R1 receptor gene expression in IK cells, obtained by RNase protection assay (2); we show that $\mathrm{R} 1$ receptors in these cells belong to the $\mathrm{CRH}-\mathrm{R} 1 \alpha$ subtype (Fig. 2). IK cells did not appear to express any of the CRH-R2 receptor subtypes (not shown).

We used the RNase protection technique to investigate whether the gene expression of CRH-R1 in IK cells is reduced after exposure to the ligand, which would result in receptor down-regulation similar to that observed in neuroendocrine tissues challenged with $\mathrm{CRH}$. For this purpose, we carried out time-course experiments looking at CRH-R1 mRNA expression after different times of exposure to $\mathrm{CRH}$ given at $10^{-7} \mathrm{M}$ concentration. Fig. 3 shows that there was no change in CRH-R1 gene expression throughout the $24 \mathrm{~h}$ of treatment with CRH.

The RNase protection technique was also used to examine CRH-R1 gene expression in 19 specimens taken from patients with endometrial cancer (Table I); total RNA extracted from IK cells was taken as positive control. CRH-R1 mRNA was expressed in 4 out of 19 specimens $(21.0 \%$ ) (Table I and 


\section{CRH (100 nM)}

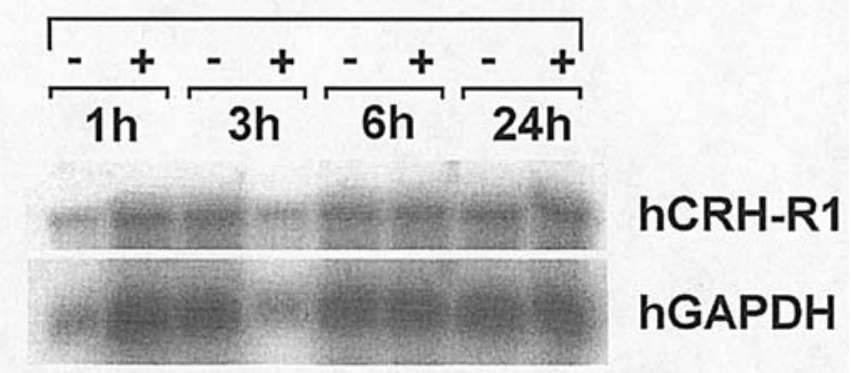

Figure 3. Treatments of IK cells with $10^{-7} \mathrm{M}$ CRH do not modify CRH-R1 expression with respect to controls treated with vehicle at any of the timepoints tested. The intensity of the protected CRH-R 1 fragments was normalized to the intensity of the protected GAPDH fragment of the same sample. A representative of three experiments is shown.

Fig. 4). Although our finding has to be considered with caution due to the relatively small sample series, we found that cases which do not express CRH-R1 mRNA had tumors limited to uterine corpus (FIGO stage I), while 2 out of 4 cases $(50 \%)$ expressing CRH-R1 mRNA, had extrauterine disease $(\mathrm{p}=0.015)$. On the other hand, we failed to find any association between CRH-R1 mRNA expression and the other clinico-pathological features.

\section{Discussion}

In this study, we showed that IK cells normally express CRH$\mathrm{R} 1 \alpha$ receptor subtype, whose activation by the ligand is able to antagonize the stimulus to cell proliferation induced by estrogens. The CRH-R1 $\alpha$ subtype has been described in human reproductive tissues in an exquisite physiological paradigm, i.e. chorionic villi of placenta at term, where the receptor is associated to syncytiotrophoblast but not to cytotrophoblast, and appears to mediate the effects of $\mathrm{CRH}$ on parturition timing $(5,10)$. The finding of CRH-R $1 \alpha$ in IK cells reinforces the concept that this tumor line retains several features of normal endometrium (including responsiveness to estradiol, as also shown in the present study).

$\mathrm{CRH}-\mathrm{R} 1 \alpha$ receptors in IK cells maintain their normal function as mediators of $\mathrm{CRH}$ actions; in fact, the peptide was able to antagonize the proliferative activity of estradiol. From a pharmacological viewpoint, such effect of CRH can be defined as a functional antagonism, since the peptide neither competes with estrogen for binding sites, nor does it appear to interfere with the ER- $\alpha$ gene expression. Antagonism is most probably achieved via the activation of the cAMP-PKA cascade (2), which is known to promote differentiation in normal endometrial tissues $(11,12)$.

Here, we showed that CRH-R1 gene expression in IK does not appear to be regulated by the ligand; this is at variance with the large body of evidence obtained in normal neuroendocrine tissues (13), where exposure to CRH leads to CRHR1 down-regulation. A 24-h treatment with CRH failed to induce CRH-R1 mRNA down-regulation in ATT-20 cells (Pozzoli, unpublished data). This finding is in keeping with the observations by Iredale et al (14), and is also similar to that
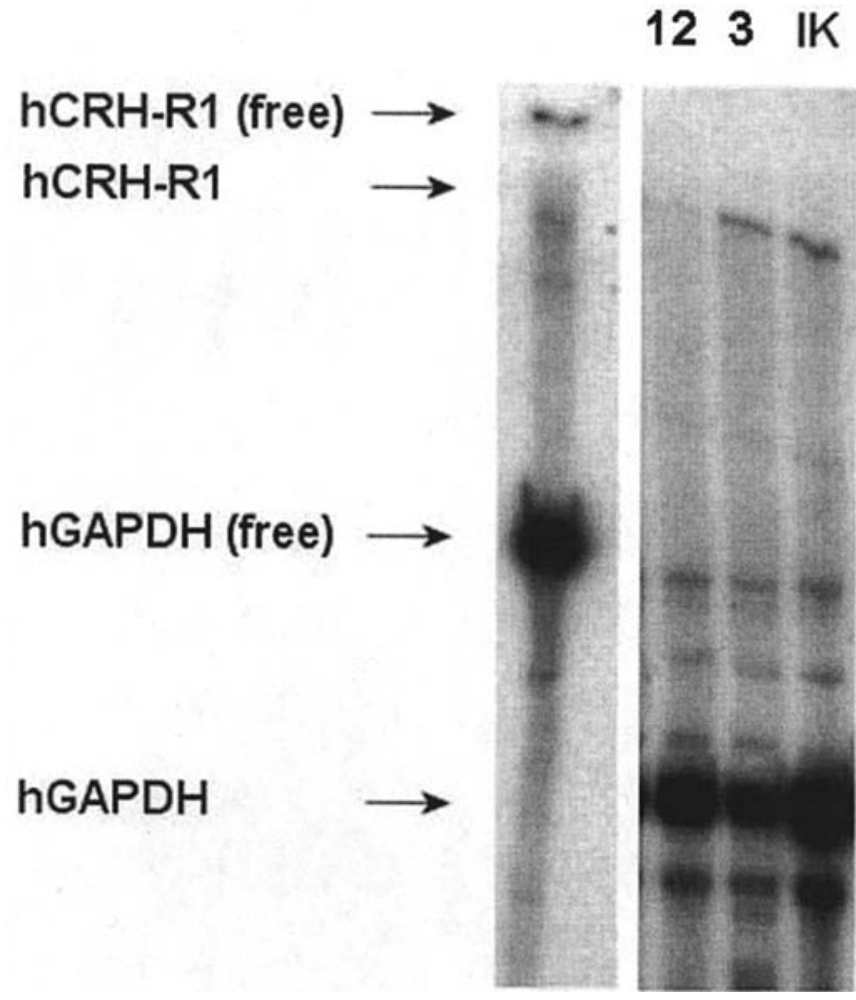

Figure 4. Autoradiogram of a representative RNase protection assay showing negative (patient 12) or positive (patient 3) CRH-R1 expression. CRH-R1 expression in Ishikawa cells (IK) as a positive internal control. The probes are shown in the first lane on the left.

obtained in IMR32, a neuroblastoma cell line expressing CRH-R1 receptors (15). On the contrary, a paradoxical upregulation of CRH-R was found by Sakai and colleagues (16) in human adenoma cells in vitro.

All of the evidence concerning IK cells, including the finding that these cells express and produce sizable amounts of immunoreactive CRH (17), indicates that the expression of CRH-R1 is associated to a phenotype close to the physiological one, and that the activation of CRH-R 1 receptor by the ligand contributes to such a phenotype by reducing cell proliferation. Thus, one would expect the expression of CRH-R1 receptor in human tumor to be associated to more differentiated benign forms. On the contrary, preliminary evidence obtained in human tumor specimens shows that the gene expression of CRH-R1 receptor subtype is detected in a minority of cases $(\sim 20 \%)$; those not expressing CRH-R 1 mRNA were all stage I disease, while 2 out of 4 cases expressing CRH-R 1 mRNA suffered extra-uterine disease. Although these data have to be considered with caution, it is conceivable that CRH-R1 expression characterize endometrial tumors with a more aggressive pattern. Obvious differences exist between cell lines and human tumor tissues that can account for the discrepancies observed here. In particular, differences might derive from the presence (or the absence) in human tumors of $\mathrm{CRH}$ receptors type-2, which are not expressed in IK cells and have been shown to mediate the suppression of angiogenesis (18). Studies are currently underway in our laboratory to clarify this point. 


\section{Acknowledgements}

This study was supported in part by 'Programmi di ricerca scientifica di rilevante interesse nazionale' (PRIN) project to G.G., and in part by Fondi di Ateneo 2004 to P.N.

\section{References}

1. Melzig MF: Corticotropin releasing factor inhibits proliferation of AtT-20 cells. In Vitro Cell Dev Biol 30A: 741-743, 1994.

2. Graziani G, Tentori L, Portarena I, Barbarino M, Tringali G, Pozzoli G and Navarra P: Corticotropin-releasing hormone inhibits cell growth of human endometrial adenocarcinoma cells via CRH-receptor 1-mediated activation of cAMP-protein kinase A pathway. Endocrinology 143: 807-813, 2002.

3. Arbiser JL, Karalis K, Viswanathan A, Koike C, Anand-Apte B, Flynn E, Zetter B and Majzoub JA: Corticotropin-releasing hormone stimulates angiogenesis and epithelial tumor growth in the skin. J Invest Dermatol 113: 838-842, 1999.

4. Reubi JC, Waser B, Vale WW and Rivier J: Expression of CRF1 and CRF2 receptors in human cancers. J Clin Endocrinol Metab 88: 3312-3320, 2003.

5. Majzoub JA and Karalis K: Placental corticotropin-releasing hormone: function and regulation. Am J Obstet Gynecol 180: S242-S246, 1999.

6. Ferrari A, Petraglia F and Gurpide E: Corticotropin releasing factor decidualizes human endometrial stromal cells in vitro. Interaction with progestin. J Steroid Biochem Mol Biol 54: 251-255, 1995.

7. Petterson F: Annual Report on the Results of Treatment in Gynecologic Cancer. FIGO, Stockholm, 1988.

8. Chomczynski P and Sacchi N: Single-step method of RNA isolation by acid guanidinium thiocyanate-phenol-chloroform extraction. Anal Biochem 162: 156-159, 1987.

9. Pozzoli G, Bilezikjian LM, Perrin MH, Blount AL and Vale WW: Corticotropin-releasing factor (CRF) and glucocorticoids modulate the expression of type $1 \mathrm{CRF}$ receptor messenger ribonucleic acid in rat anterior pituitary cell cultures. Endocrinology 137: 65-71, 1996.
10. Karteris E, Grammatopoulos D, Dai Y, Olah KB, Ghobara TB, Easton A and Hillhouse EW: The human placenta and fetal membranes express the corticotropin-releasing hormone receptor 1alpha (CRH-1alpha) and the CRH-C variant receptor. J Clin Endocrinol Metab 83: 1376-1379, 1996.

11. Tang B, Guller S and Gurpide E: Cyclic adenosine 3',5'monophosphate induces prolactin expression in stromal cells isolated from human proliferative endometrium. Endocrinology 133: 2197-2203, 1993.

12. Telgmann R, Maronde E, Taskén K and Gellersen B: Activated protein kinase $\mathrm{A}$ is required for differentiation-dependent transcription of decidual prolactin gene in human endometrial stromal cells. Endocrinology 138: 929-937, 1997.

13. Aguilera G, Rabadan-Diehl C and Nikodemova M: Regulation of pituitary corticotropin releasing hormone receptors. Peptides 22: 769-774, 2001.

14. Iredale PA and Duman RS: Glucocorticoid regulation of corticotropin-releasing factor 1 receptor expression in pituitaryderived AtT-20 cells. Mol Pharmacol 51: 794-799, 1997.

15. Roseboom PH, Urben CM and Kalin NH: Persistent corticotropinreleasing factor(1) receptor desensitization and downregulation in the human neuroblastoma cell line IMR-32. Brain Res Mol Brain Res 92: 115-127, 2001.

16. Sakai Y, Horiba N, Sakai K, Tozawa F, Kuwayama A, Demura H and Suda T: Corticotropin-releasing factor up-regulates its own receptor gene expression in corticotropic adenoma cells in vitro. J Clin Endocrinol Metab 82: 1229-1234, 1997.

17. Makrigiannakis A, Zoumakis E, Margioris AN, Stournaras C, Theodoropoulos P and Gravanis A: The corticotropin-releasing hormone (CRH) in normal and tumoral epithelial cells of human endometrium. J Clin Endocrinol Metab 79: 185-189, 1995.

18. Bale TL, Giordano FJ, Hickey RP, Huang Y, Peterson KL, Nath AK, Vale WW and Lee K-F: Corticotropin-releasing factor receptor 2 is a tonic suppressor of vascularization. Proc Natl Acad Sci USA 99: 7734-7739, 2002. 